\title{
Effect of Growth hormones for direct organogenesis in Bael (Aegle marmelos (L.) corr)
}

\author{
Usha Kumari. R, S.M. Lakshmi and G.Thamodharan* \\ Agricultural College and Research Institute, Madurai 625 104, INDIA \\ *Corresponding author. E-mail: srig852@gmail.com \\ Received: September 12, 2014; Revised received: February 13, 2015; Accepted: March 11, 2015
}

Abstract: Aegle marmelos (L.) corr. commonly known as 'Bael' tree is included in the red- listed medicinal tree in South India. Riped and unripe fruits, root, bark and leaves of the tree are used in ayurvedic preparation for various ailments. This study was conducted to standardize the media for multiple shoot induction from different explants under in vitro condition. Among the various explants viz., meristematic tip, nodal bud, tender leaf, auxillary bud and cotyledon tried in different media, auxiliary bud had shown good response for shoot induction in 36 to 39 days. Among the various treatments viz., WPM supplemented with Benzyl Amino Purine (BAP) (0.5 to $3.0 \mathrm{mg} / \mathrm{lit})$, Kinetin $(\mathrm{KN})(0.5$ to $3 \mathrm{mg} / \mathrm{lit})$ and Indole acetic acid (IAA) (0.5 to $2 \mathrm{mg} / \mathrm{lit})$ for multiple shoot induction, the treatmental combination of WPM supplemented with BAP, KN and IAA, @ of each $0.5 \mathrm{mg} / \mathrm{lit}$ resulted in 7.75 shoots per cotyledon. The same combination, $1 / 2$ strength of the medium with $1 \mathrm{mg} /$ lit $B A P+2 \mathrm{mg} / \mathrm{lit} \mathrm{NAA}+1 \% \mathrm{AC}$ resulted in root formation. Hence, as a means of in vitro conservation using cotyledon as explants microproagation is possible in bael.

Keywords: Bael; hormonal combination; multiple shoot; Shoot induction; Root induction

\section{INTRODUCTION}

Bael (Aegle marmelos Corr.) is an important medicinal fruit tree which belongs to the family Rutaceae and growing wildly in India, is in high demand for pharmaceutical purposes (Hazeena and Sulekha, 2008). All parts of the tree are used in ayurvedic preparation for various ailments. The fruit pulp contains marmelosin, which is a laxative, diuretic, is being used in many patented drugs in India (Pati and Muthukumar, 2013). The plant products obtained from bael are highly nutritive and therapeutic. The riped fruits are used for dyspepsia and the unripe and half riped fruits improve appetite and digestion (Shailajan et al., 2011). The root and bark of the tree are used in the treatment of fever and abdominal pain. Due to its high medicinal value it is being exploited to a larger extent by the drug and pharmaceutical industries. Thereby it is included in the red- listed medicinal tree in South India (Ravikumar and Ved 2000). The bael tree can suitably be grown under various wasteland situations. However, its commercial orcharding is not expanding at a faster pace due to severe shortage of planting material. Conventional method of bael propagation (Inarching, budding and soft wood grafting) is season bound and slow. The seeds produced this kind of endangered species are mostly very small in number or they do not have potential to germinate. Micropropagation technology can be gainfully employed in mass multiplication of improved bael varieties (Pradeepa Devi et al., 2014). To accomplish in this contest an attempt was made to standardize the media for tissue culture so as to conserve the species in vitro.

\section{MATERIALS AND METHODS}

Ripened fruits were collected from twenty year old tree of A.marmelos grown at Vivekananda ashram, Thiruvedagam, Madurai district which was originally brought from kasi hills. Seeds were removed from the fruits with the help of scalpel and washed in tap water to remove the pulp adhered on them. The explants viz., meristematic tip $\left(E_{1}\right)$, nodal bud $\left(E_{2}\right)$, tender leaf $\left(E_{3}\right)$, auxillary bud $\left(E_{4}\right)$ were collected from vilvam seedling sown in pot and cotyledon $\left(\mathrm{E}_{5}\right)$ collected aseptically from $24 \mathrm{hrs}$ water soaked seeds and washed thoroughly for 15 to 20 minutes in tap water. The explants were dipped in $70 \%$ ethanol for 5 minutes and rinsed thoroughly in sterile distilled water. Surface sterilization was carried out with $0.1 \%$ mercuric chloride for 5 minutes followed by rinsing thrice with sterile distilled water. These explants were spread out in sterile filter paper to remove excess water before being cultured on selected nutrient media with growth hormonal combination. The media viz.,MS medium (Murashige and Skoog, 1962), B 5 medium (Gamborg et al., 1968) and WPM Woody Plant Medium (Lyoyd and McCown 1980) were tried to find out the response of the explants for invitro culture. Among the media WP media responded well and selected for further treatmental combination. The sterilized explants were aseptically transferred to woody plant medium supplemented with $2 \%$ sucrose and $0.8 \%$ agar along with four different hormonal combinations viz., Plain medium $\left(\mathrm{T}_{1}\right)$, Medium + 0.5 mg/lit Kinetin $(\mathrm{KN})+0.5 \mathrm{mg} / \mathrm{lit}$ Benzyl amino purine $(\mathrm{BAP})+0.5 \mathrm{mg} / \mathrm{lit}$ Indole acetic acid 
(IAA) $\left(\mathrm{T}_{2}\right)$, Medium $+1.0 \mathrm{mg} / \mathrm{lit} \mathrm{KN}+1.0 \mathrm{mg} / \mathrm{lit}$ $\mathrm{BAP}+1.0 \mathrm{mg} / \mathrm{lit} \mathrm{IAA}\left(\mathrm{T}_{3}\right)$, Medium $+2.0 \mathrm{mg} / \mathrm{lit}$ $\mathrm{KN}+2.0 \mathrm{mg} / \mathrm{lit} \mathrm{BAP}+1.0 \mathrm{mg} / \mathrm{lit} \mathrm{IAA}\left(\mathrm{T}_{4}\right)$ and medium $+3.0 \mathrm{mg} / \mathrm{lit} \mathrm{KN}+3.0 \mathrm{mg} / \mathrm{lit} \mathrm{BAP}+1.0 \mathrm{mg} / \mathrm{lit}$ IAA $\left(\mathrm{T}_{5}\right)$ for shoot induction. For root induction half strength WP medium supplemented with $2 \%$ sucrose and $0.8 \%$ agar along with activated charcoal and growth hormones viz., IAA, IBA and NAA as $1 / 2$ strength Medium $+2 \mathrm{mg} / \mathrm{lit} \mathrm{IAA}+1 \mathrm{mg} / \mathrm{lit} \mathrm{NAA}\left(\mathrm{T}_{1}\right)$, $1 / 2$ strength medium $+1 \mathrm{mg} / \mathrm{lit} \mathrm{BAP}+2 \mathrm{mg} / \mathrm{lit} \mathrm{NAA}+$ $1 \%$ activated charcoal $(\mathrm{AC})\left(\mathrm{T}_{2}\right), 1 / 2$ strength medium $+1.0 \mathrm{mg} / \mathrm{lit} \mathrm{KN}+1.0 \mathrm{mg} / \mathrm{lit} \mathrm{BAP}+2.0 \mathrm{mg} / \mathrm{lit} \mathrm{IBA}+$ $2 \mathrm{mg} / \mathrm{lit} \mathrm{NAA}+1 \% \mathrm{AC}\left(\mathrm{T}_{3}\right), \quad 1 / 2$ strength medium + $1.0 \mathrm{mg} / \mathrm{lit} \mathrm{KN}+3.0 \mathrm{mg} / \mathrm{lit} \mathrm{IAA}+1.0 \mathrm{mg} / \mathrm{lit} \mathrm{NAA}\left(\mathrm{T}_{4}\right)$, $1 / 2$ strength medium $+1.0 \mathrm{mg} / \mathrm{lit} \mathrm{BAP}+3.0 \mathrm{mg} / \mathrm{lit}$ $\mathrm{NAA}+1.0 \mathrm{mg} / \mathrm{lit} \mathrm{IBA}+1 \% \mathrm{AC}\left(\mathrm{T}_{5}\right)$ and $1 / 2$ strength medium $+0.5 \mathrm{mg} / \mathrm{lit} \mathrm{KN}+3.0 \mathrm{mg} / \mathrm{lit} \mathrm{IBA}+1.0 \mathrm{mg} / \mathrm{lit}$ IAA $\left(\mathrm{T}_{6}\right)$. Four replication sets for each treatment was maintained for all the experiments. The $\mathrm{pH}$ of the medium was adjusted to 5.7 prior to autoclaving at 15 pound pressure for 20 minutes. The explants were inoculated under sterile condition and incubated at $25 \pm 2^{\circ} \mathrm{C}$, at a relative humidity of $60-70$ percent with a light intensity of 3000 lux using white fluorescent lamps. A photoperiod of $16 \mathrm{hrs}$ light and dark cycle was maintained.

Cultures were observed daily for finding out the number of days taken for shoot initiation. No. of shoots emerged from each explants was recorded after 45 days of inoculation. The shoot were sub cultured for further growth and after attainment to a height of $2 \mathrm{~cm}$ the shoots were transferred to rooting media and number of days taken for root initiation was observed and recorded.
Statistical analysis: Each experiment was set up as a completely randomized design (CRD). Data were subjected to analysis of variance (ANOVA). Means were compared using the least significant difference (LSD) test at 0.01 level of probability.

\section{RESULTS AND DISCUSSION}

Micropropagation is a method of rapid clonal propagation of valuable endangered medicinal plants like wood apple (commonly called "bael") and other seasonal bound plant species. Micropropagation of woody natured species lagging with some difficulty due to slow response to applied medium, presence of phenolic exudates, inherent slow growing habit, long complex life cycles and great genetic variations (Rekha Warrier et al., 2010). So it is essential that to standardize the regeneration protocol to efficient establishment of given species under in vitro condition. Standardization begins with use of various media and different hormonal concentration to different explants. Various literatures supported that cytokine: auxin ratio is the deciding factor in the establishment of efficient reproducible protocol. Higher cytokine and low auxin concentration helps to multiple shoot proliferation. Among the various explants used for this study embryo break was observed in cotyledonary explants maintained in woody plant medium (WPM) supplemented with growth hormones in sixth week after inoculation. Subsequently in seventh and eighth weeks there was emergence of multiple shoots from the break. It showed slow response for shoot induction as compared to auxillary bud where shoot induction was observed on fifth week after inoculation and was considered as best explant for shoot induction (Table 1) followed by

Table 1. Response of explants/hormones on multiple shoot induction in woody plant medium in days.

\begin{tabular}{lcccc}
\hline S. No. & Explants & T $_{\mathbf{1}}$ (in days) & T $_{\mathbf{2}}$ (in days) & T $_{\mathbf{3}}$ (in days) \\
\hline 1 & $\mathrm{E}_{1}$ & $46.5^{\mathrm{b}}$ & $44.75^{\mathrm{b}}$ & $47^{\mathrm{b}}$ \\
2 & $\mathrm{E}_{2}$ & $44.5^{\mathrm{b}}$ & $42.5^{\mathrm{b}}$ & $46.25^{\mathrm{b}}$ \\
3 & $\mathrm{E}_{3}$ & $58^{\mathrm{d}}$ & $57.25^{\mathrm{d}}$ & $58.75^{\mathrm{d}}$ \\
4 & $\mathrm{E}_{4}$ & $38^{\mathrm{a}}$ & $36.75^{\mathrm{a}}$ & $39^{\mathrm{a}}$ \\
5 & $\mathrm{E}_{5}$ & $53.5^{\mathrm{c}}$ & $51.5^{\mathrm{c}}$ & $54.25^{\mathrm{c}}$ \\
\hline SED & & 1.3540 & 1.5916 & 1.1583 \\
CD $(0.01 \%)$ & & 3.9900 & 4.6902 & 3.4133 \\
\hline
\end{tabular}

Table 2. Response of explants/hormones on number of shoots in woody plant medium

\begin{tabular}{lcccc}
\hline S.N. & Explants & $\begin{array}{c}\mathbf{T}_{\mathbf{1}} \text { (Number of } \\
\text { shoots) }\end{array}$ & $\begin{array}{c}\mathbf{T}_{2} \text { (Number of } \\
\text { shoots) }\end{array}$ & $\begin{array}{c}\mathbf{T}_{\mathbf{3}} \text { (Number of } \\
\text { shoots) }\end{array}$ \\
\hline 1 & $\mathrm{E}_{1}$ & $1^{\mathbf{c}}$ & $1.25^{\mathbf{c}}$ & $0.25^{\mathbf{c}}$ \\
2 & $\mathrm{E}_{2}$ & $1^{\mathbf{c}}$ & $2.00^{\mathbf{b c}}$ & $0.50^{\mathbf{c}}$ \\
3 & $\mathrm{E}_{3}$ & $2.75^{\mathbf{b}}$ & $3.25^{\mathbf{b}}$ & $2.50^{\mathbf{b}}$ \\
4 & $\mathrm{E}_{4}$ & $2.50^{\mathbf{b}}$ & $3.75^{\mathbf{b}}$ & $2.00^{\mathbf{b}}$ \\
5 & $\mathrm{E}_{5}$ & $6.25^{\mathbf{a}}$ & $7.75^{\mathbf{a}}$ & $5.50^{\mathbf{a}}$ \\
$\mathrm{SED}$ & & 0.4655 & 0.8367 & 0.5083 \\
$\mathrm{CD}$ & & 1.3717 & 2.4655 & 1.4977 \\
$(0.01 \%)$ & & & & \\
\hline
\end{tabular}




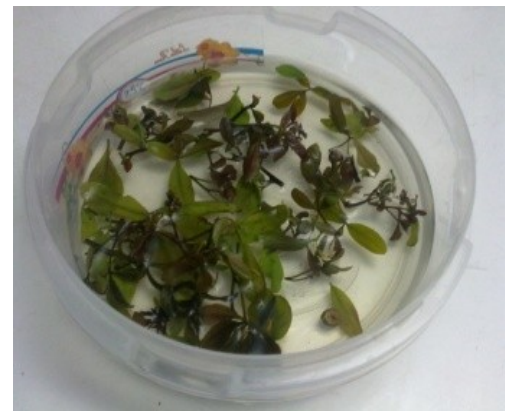

Seed extracted from fruit

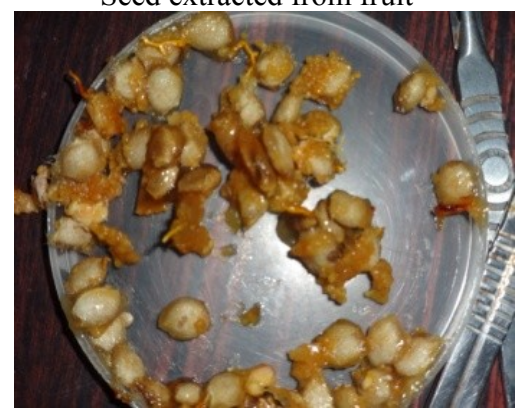

Vilvam fruit

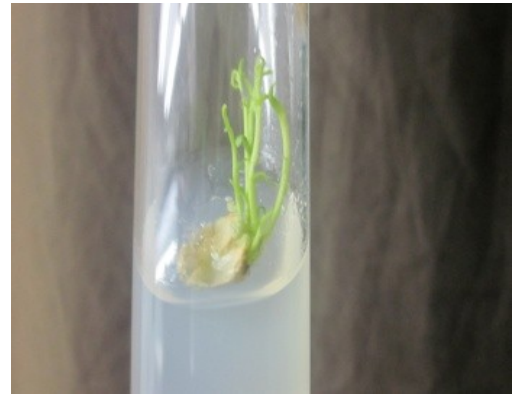

Multiple shoot from cotyledon

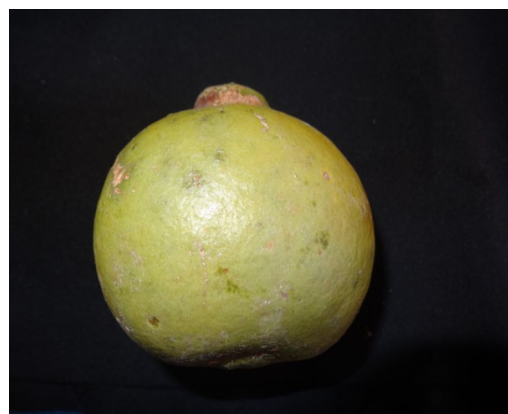

Vilvam leaf explants

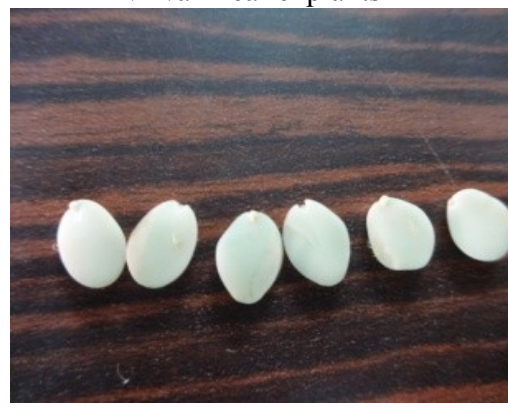

Exercised young embryo

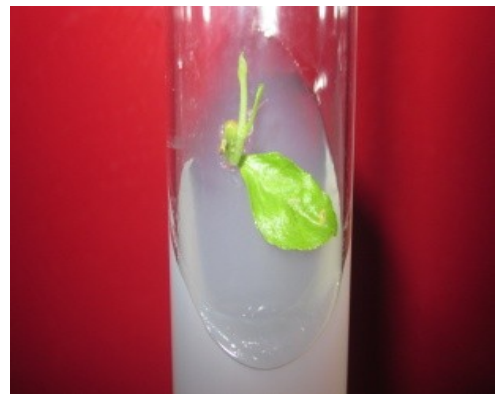

Multiple shoot from auxillary bud

Fig. 1. Various source of explants (Leaf, seed and young embryo) and regeneration of multiple shoot.

Table 3. Response of explants/hormones on root induction in woody plant medium in days .

\begin{tabular}{lcc}
\hline S.N. & Explants & T $_{2}$ (in days) \\
\hline 1 & $\mathrm{E}_{1}$ & $35.75^{\mathbf{e}}$ \\
2 & $\mathrm{E}_{2}$ & $32.50^{\mathbf{d}}$ \\
3 & $\mathrm{E}_{3}$ & $27.50^{\mathbf{c}}$ \\
4 & $\mathrm{E}_{4}$ & $21.00^{\mathbf{a}}$ \\
5 & $\mathrm{E}_{5}$ & $23.00^{\mathbf{b}}$ \\
\hline SED & & 0.6519 \\
$\mathrm{CD}(0.01 \%)$ & & 1.9211 \\
\hline
\end{tabular}

nodal bud which induced shoot on sixth week after inoculation. Irrespective of explants the treatment $\mathrm{T}_{2}$ (Medium $+0.5 \mathrm{mg} / \mathrm{lit} \mathrm{KN}+0.5 \mathrm{mg} / \mathrm{lit} \mathrm{BAP}+0.5 \mathrm{mg} / \mathrm{lit}$ IAA), was considered to be best than other treatments for shoot induction. This was accordance with result of Puhan and Rath (2012) in bael, reported that when nodal explants ware transferred into the same basal medium supplemented with $0.5 \mathrm{mg} \mathrm{BA} / 1$ with different concentrations of either kinetin $(\mathrm{KN})$ or gibberellic acid (GA3) or in combinations has shown healthy shoots with expanded shoot length. $\mathrm{T}_{2}$ was observed as best treatment for number of shoots and irrespective of treatment the cotyledonary explant was found to be best in emergence of number of shoots and the number of shoots emerged at higher concentration of BAP was less than lower concentration of BAP (Table 2). Multiple shoot bud formation from the young shoot tip explant of Clitoria ternatea on $0.5 \mathrm{mg} / \mathrm{l} \mathrm{BAP}$ with lower concentrations of NAA or IAA has also been reported by Kalamani and Michael Gomez (2002). The effect of BAP on shoot formation had been reported by (Purohit, et al., 1995) for medicinal and aromatic plant species Chlorophytum borivilianum. The treatment $\mathrm{T}_{4}$ did not show response in terms of shoot induction. Explant sources and regeneration of multiple shoots are represented in Fig. 1

Treatment $\mathrm{T}_{2}(1 / 2$ strength medium $+1 \mathrm{mg} / \mathrm{lit}$ BAP +2 $\mathrm{mg} / \mathrm{lit} \mathrm{NAA}+1 \%$ activated charcoal (AC), alone responded for root formation of multiple shoot on Woody Plant Medium under in vitro condition (Table 3). The shoot in the rooting medium devoid of charcoal dried up, this may be due to oxidation. Charcoal was 
also used to reduce the light effect. The treatment $T_{1}$, $\mathrm{T}_{3}, \mathrm{~T}_{4}$ and $\mathrm{T}_{5}$ did not show response in terms of root induction on applied medium.

\section{Conclusion}

Among the various treatments viz., WPM supplemented with Benzyl Amino Purine (BAP) (0.5 to $3.0 \mathrm{mg} / \mathrm{lit}$ ), Kinetin (KN) $(0.5$ to $3 \mathrm{mg} / \mathrm{lit})$ and Indole acetic acid (IAA) $(0.5$ to $2 \mathrm{mg} / \mathrm{lit})$ for multiple shoot induction, the treatmental combination of WPM supplemented with BAP, KN and IAA, @ of each $0.5 \mathrm{mg} /$ lit resulted in 7.75 shoots per cotyledon. The same combination, $1 / 2$ strength of the medium with $1 \mathrm{mg} / \mathrm{lit} \mathrm{BAP}+2 \mathrm{mg} / \mathrm{lit}$ $\mathrm{NAA}+1 \% \mathrm{AC}$ resulted in root formation. Hence as a means of in vitro conservation using cotyledon as explants microproagation is possible in bael.

\section{ACKNOWLEDGEMENT}

The authors express their deep felt gratitude to University Grant Commission, New Delhi (F. No. 41-1205/2012 (SR), dt.26.07.2012) for providing funds for this research.

\section{REFERENCES}

Gamborg O.L., R.A. Miller and O. Ojima. (1968). Nutrient requirements of suspension cultures of soybean root cell. Exp. Cell Res., 50: 151-158.

Hazeena, M.S. and G.R. Sulekha. (2008). Callus induction and plantlet regeneration in Aegle marmelos (L.) Corr. using cotyledon explants. Journal of Tropical Agriculture., 46 (1-2): 79-84.

Kalamani, A. and S. Michael Gomez (2002). In vitro propagation studies in Clitoria spp. International Journal Mendel,
19(2):29-30.

Lloyd, G. and B. McCown. (1980). Commercially feasible micropropagation of mountain laurel, Kalmia latifolia by use of shoot tip culture. Proc. Intl. Plant Prop. Soc., 30: 421-427.

Murashige, T. and Skoog, F. (1962): A revised medium for rapid growth and bioassay with tobacco tissue cultures. Physiologia Plantarum, 15: 473-495.

Pati. and M. Muthukumar. (2013). Genetic Transformation of Bael (Aegle marmelos. Corr.) Biotechnology of Neglected and Underutilized Crops, DOI: 10.1007/978-94-007-5500-0_14.

Pradeepa Devi, C.B., R.M. Gopal and A. Settu. (2014). Plant regeneration of Aegle marmelos (L.) corr. from cotyledon explants through in vitro studies. J. Nat. Prod. Plant Resour., 4 (2):52-55.

Purohit, S.D., A. Dave, and G. Kukda. (1995) Micropropagation of safed musli (Chlorophytum borivilianum), a rare medicinal herb. Plant Cell, Tissue and Organ Culture, 39: 93-96.

Puhan, Puspashree P. and Rath, S.P. (2012). In vitro propagation of Aegle marmelos (L.) Corr., a medicinal plant through axillary bud multiplication. Advances in Bioscience and Biotechnology, 3: 121-125

Ravikumar, K. and. K. Ved. (2000). Aegle marmelos, 100 Red - Listed medicinal plants of Conservation Concern in Southern India., Foundation for Revitalisation of Local Health Traditions, Bangalore. pp: 41-43.

Rekha Warrier., Jasmine Viji and P. Priyadharshini. (2010). In Vitro Propagation of Aegle Marmelos L. (Corr.) from mature trees through enhanced axilliary brancing. Asian J. Exp. Biol. Sci., 1 (3): 669-676.

Shailajan, S., S. Menon and H. Hande. (2011). Method validation of Marmelosin from fruit pulp of Aegle marmelos (L.) Correa using HPTLC Technique. J. Pharm. Res., 4 (5):1353-1355. 